\title{
The Redox Potential of Hot Springs in Taiwan
}

\author{
Wen-Fu Chen ${ }^{1, *}$ and Menghau Sung ${ }^{2}$ \\ ${ }^{1}$ Institute of Hot Spring Industry, Chia-Nan University, Tainan, Taiwan, ROC \\ ${ }^{2}$ Department of Environmental Science and Engineering, Tunghai University, Taichung, Taiwan, ROC
}

Received 1 February 2008, accepted 11 June 2008

\begin{abstract}
Scientists began acquiring the basic of geology, occurrence, water temperature and chemistry of hot springs in Taiwan over a century ago. However, data regarding redox potential and important redox couples still remains limited. This study explores the redox status of hot springs in Taiwan by measuring Eh in the field and by determining the concentrations of commonly found redox couples, i.e., $\mathrm{O}_{2} / \mathrm{H}_{2} \mathrm{O}, \mathrm{NO}_{3}{ }^{-} / \mathrm{NH}_{4}{ }^{+}$, and $\mathrm{HS}^{-} / \mathrm{SO}_{4}{ }^{-2}$. Water samples were collected at hot spring discharge pools or the heads of water wells using a pump. A total of 11 hot springs located at 9 different locations across Taiwan were surveyed.

The measured values of Eh ranging from -23 to $-277 \mathrm{mV}$ indicate reducing conditions. Most of the water samples from the hot spring sources contained sulfide and ammonium. In the Tatun Volcano Group, hot springs originating from a mixture of fumarolic gas and stream water contained high concentrations of hydrogen sulfide as the dominant reducing agent. Ammonium, with concentrations ranging from 1 to $55 \mathrm{mg} \mathrm{L}^{-1}$, is another important electron donor.

The finding revealed that there were negative Eh measured-values for dissolved oxygen-contained waters, both in the field and in the laboratory. The presence of sulfide or ammonium was also detected in the samples. These results confirm that the Eh sensor displayed a more heightened sensitivity to sulfide and ammonium than dissolved oxygen and nitrate. Hot springs with deep circulations (Samples S1-S4 and M1-M4) lack in oxygen gas and may react with mineral reducers such that they will consequently be in a reducing state rather than oxidizing. Hot spring waters containing dissolved oxygen (S2, S4, and M2) and nitrate (S3, S4, and M2-M4) most likely have mixed with shallow groundwaters.

Discussions reveal implications for redox potentials and redox couples for arsenic speciation, disinfection of ammonium-containing hot springs for the spa industry as well as the possibility of using redox potentials and couples as indices for monitoring earthquakes and volcanic activity.
\end{abstract}

Key words: Hot spring, Redox potential, Ammonium, Sulfide, Taiwan

Citation: Chen, W. F. and M. Sung, 2009: The redox potential of hot springs in Taiwan. Terr. Atmos. Ocean. Sci., 20, 465-479, doi: 10.3319/ TAO.2008.06.11.02(TT)

\section{INTRODUCTION}

Beginning with early scientific investigations by Japanese scholars, the hot springs of Taiwan have been studied for more than one hundred years (Yen 1955). After World War II, the Mineral Research Service Organization (MRSO 1969, 1970, 1971, 1973, 1975, 1977, 1978, 1979, 1980) conducted systematical and detailed studies of Taiwan's hot springs for geothermal resources exploration; these studies produced a number of reports and hundreds of borehole records. Recently, ERL (Energy and Resources Laboratories,

\footnotetext{
* Corresponding author

E-mail:chenwenfu@mail.chna.edu.tw
}

Industrial Technology Research Institute) with financial support from the Water Resource Agency of Taiwan conducted a review of 121 hot springs in Taiwan (ERL 1999 2003) to improve hot spring tourism management and protect these water resources. In 2003, the Hot Spring Act was announced to help conserve and sustain the use of hot springs, provide auxiliary therapeutic venues, enhance national health, develop tourism, and advance public welfare (WRA 2003).

The basic knowledge of geology, occurrence, water temperature and chemistry of hot springs dated back a century (ERL 1999 - 2003); however, data pertaining to redox poten- 
tials is limited. The redox potential of water is an important parameter representing the interaction between oxidizable and reducible species in water, rock, sediments, and biota. Many elements are involved in redox reactions and are represented by a variety of species. For example, the most common oxidation states for arsenic are +3 (arsenites) and +5 (arsenates) (Brookins 1988; Hem 1992; Chapelle 2001). Arsenic concentrations are commonly high in hot springs. Its appearance is usually associated with volcanism and magmatism. The consumption of arsenic contaminated water is correlated with increased incidences of cancer among human populations. Redox reactions of arsenic are directly linked to this problem because these reactions modulate arsenic toxicity and arsenic mobility into water. Reducing states of arsenate are particularly problematic because they generate arsenite, which is more toxic and hydrologically more mobile. Conversely, arsenite oxidation counteracts these activities by transforming toxic arsenite into a less toxic form (arsenate) that preferentially partitions into sediments, thus impeding the contamination process. To determine species of arsenic, its transformation in hot spring outflows and impact on water resources, it is necessary to measure redox potential and redox couples in hot springs (Nordstrom et al. 2003).

The purpose of this study is to explore the redox environment of Taiwan's hot springs by measuring Eh in the field and to determining concentrations of commonly found redox couples, i.e., $\mathrm{NO}_{3}{ }^{-} / \mathrm{NH}_{4}{ }^{+}, \mathrm{HS}^{-} / \mathrm{SO}_{4}{ }^{-2}$. The results will assist in physical and chemical interpretations of hot springs, i.e., rock/water interaction and trace element speciation.

A total of 11 hot springs located at 9 different areas in Taiwan were surveyed, including Elite (V1), Tien-Lai (V2),
Tien-Hsyang (V3), Future Town (S1), Jin-Ping (S2), HuShan (S3), Four Season (M1), Bali Nature SPA (M2), Kylin Peak (S4), Atayal (M3), and Baolai (M4) (Table 1). By geological backgrounds, 3 of these hot springs are located in the Tatun Volcano Group, 4 in the Western Foothill, 3 in the Hsueshan Range, and 1 in the Central Range (Fig. 1).

\section{METHODS}

Water samples were collected from the outlets of springs or water wells using a pump from 23 to 25 of May 2005. Dissolved oxygen (DO), redox potential (Eh), temperature, $\mathrm{pH}$ and electrical conductivity (EC) were measured in the field (Table 2). Sensors were calibrated with standard solutions of $\mathrm{pH}=4.00,7.00$, and $10.0 ; \mathrm{EC}=1410 \mu \mathrm{S} \mathrm{cm}^{-1} ; \mathrm{Eh}=+280 \mathrm{mV}$ (all from Merck) prior to any field measurement of these parameters (APHA 1998). DO, temperature, $\mathrm{pH}, \mathrm{EC}$, and Eh were measured in a flow-through cell three times at 5-min intervals, using portable equipment: DO (Oxi 315), $\mathrm{pH}(\mathrm{pH} 315)$, Eh (pH/ION 340), and EC (Cond 300) made by Wissenschaftlich-Technische-Werkstätten (WTW Nova Analytics at Woburn of Massachusetts, USA).

The commercial combination Eh sensor, Pt4805 by Mettler Inc. in Switzerland, has sensing $(\mathrm{Pt})$ and reference ( $\mathrm{Ag} / \mathrm{AgCl})$ half-cells packaged in a single body (Fig. 2). The precious-metal electrode serves as an electron donor or electron acceptor depending upon the test solution. The Eh is related to the observed potential of the combination redox sensor as follows:

$\mathrm{Eh}=\mathrm{E}_{\text {sensor }}+\mathrm{E}_{\text {reference }}$

Table 1. Locations of the sampled hot springs in Taiwan.

\begin{tabular}{llllll}
\hline ID & \multicolumn{1}{c}{ Name } & \multicolumn{1}{c}{ Location } & \multicolumn{1}{c}{ Type* } & X $(\mathbf{m})$ & Y $(\mathbf{m})$ \\
\hline V1 & Elite & Chingshan, Taipei & Spring & 309997 & 2787598 \\
V2 & Tien-Lai & Chingshan, Taipei & Spring & 309957 & 2787721 \\
V3 & Tien-Hsyang & Beitou, Taipei & Spring & 302612 & 2781544 \\
S1 & Future Town & Linkou, Taipei & Well: WD $1500 \mathrm{~m}$ & 286097 & 2774073 \\
S2 & Jin-Pin & JienShin, Hsinchu & Well: WD $1000 \mathrm{~m}$ & 270331 & 2729598 \\
S3 & Hu-Shan & Taian, Miaoli & Spring & 246763 & 2707343 \\
S4 & Kylin Peak & Dakun, Taichung & Well: WD $2000 \mathrm{~m}$ & 223027 & 2676166 \\
M1 & Four Season & Kukuan, Taichung & Well: WD $80 \mathrm{~m}$ & 250127 & 2677939 \\
M2 & Bali Nature SPA & Kukuan, Taichung & Well: WD $150 \mathrm{~m}$ & 250246 & 2677890 \\
M3 & Atayal & Pekangshi, Nantou & Well: WD $600 \mathrm{~m}$ & 243739 & 2663025 \\
M4 & Baolai & Baolai, Kaohsiung & Spring & 220547 & 2554146 \\
\hline
\end{tabular}

* Spring: The hot water flows perennially without a pump. Well: Water pressure of hot water is under the ground surface and need a pump to withdraw its hot water. WD: Well depth of the hot spring well. 


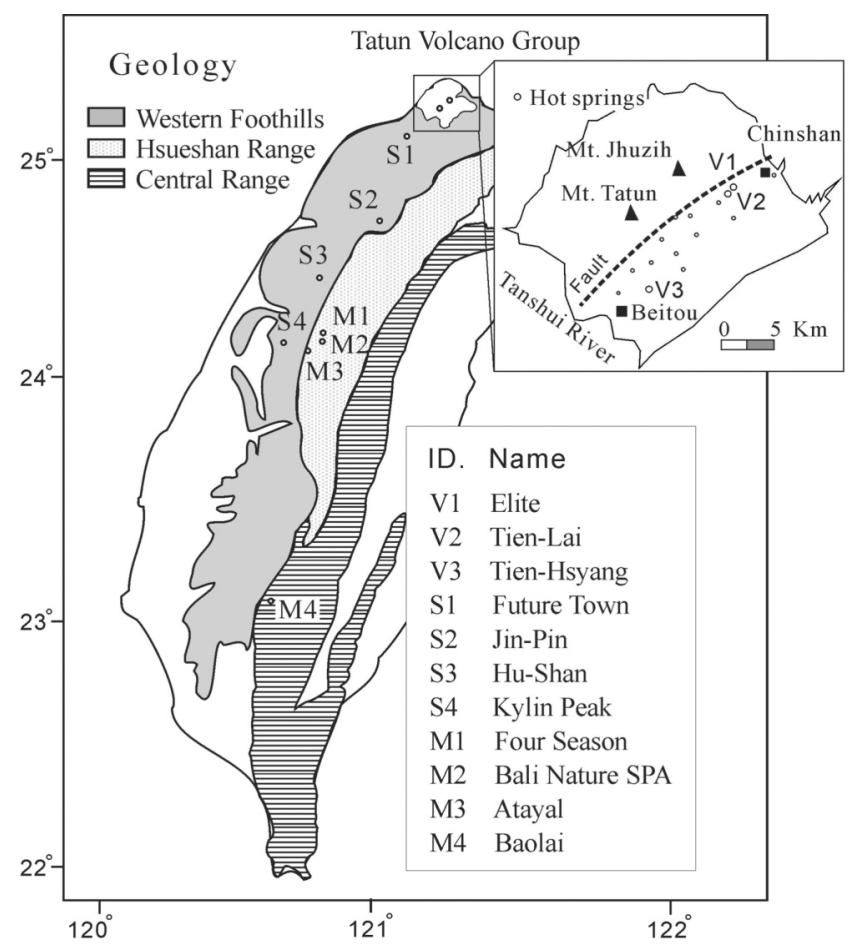

Fig. 1. Geological map of Taiwan with the locations of sampled hot springs. where $\mathrm{E}_{\text {sensor }}$ is the potential from the electrode and $\mathrm{E}_{\text {reference }}$ is the standard potential of the reference half-cell.

Water samples were collected only after $\mathrm{pH}$ and EC readings were stabilized. The fluctuations in $\mathrm{pH}$ and relative EC were found to be fewer than 0.1 and 5\%, respectively.

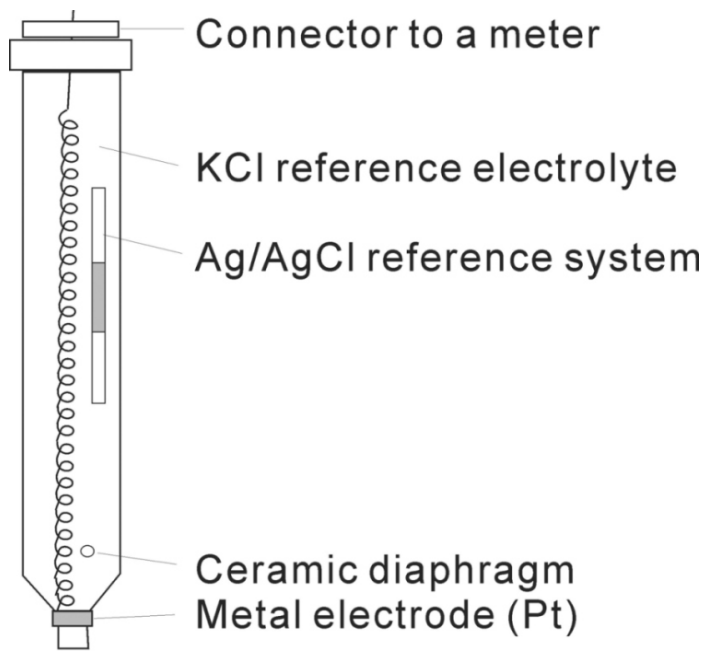

Fig. 2. The combination redox electrode (Mettler Pt4805, Switzerland).

Table 2. Analytical methods and detection limits.

\begin{tabular}{|c|c|c|c|c|c|}
\hline & & Method & Detection Limit & Unit & Note \\
\hline 1 & Temperature & NIEA W217.50 A & $0.1^{*}$ & ${ }^{\circ} \mathrm{C}$ & $\mathrm{F}$ \\
\hline 2 & $\mathrm{pH}$ & NIEA W424.50 A & $0.01^{*}$ & & $\mathrm{~F}$ \\
\hline 3 & Eh & APHA(20th) $2580 \mathrm{~B}$ & $0.1^{*}$ & $\mathrm{mV}$ & $\mathrm{F}$ \\
\hline 4 & DO & APHA(20th) 4500 OG & $0.1^{*}$ & $\mathrm{mg} \mathrm{L}^{-1}$ & $\mathrm{~F}$ \\
\hline 5 & $\mathrm{EC}$ & NIEA W203.51 B & $0.01^{*}$ & $\mu \mathrm{S} \mathrm{cm}{ }^{-1}$ & $\mathrm{~F}$ \\
\hline 6 & Alkalinity & NIEA W449.00 B & 15 & $\mathrm{mg} \mathrm{L}^{-1}$ & $\mathrm{~L}$ \\
\hline 7 & $\mathrm{Cl}^{-}$ & NIEA W415.51 B & 0.50 & $\mathrm{mg} \mathrm{L}^{-1}$ & $\mathrm{~L}$ \\
\hline 8 & $\mathrm{SO}_{4}^{-2}$ & NIEA W415.51 B & 0.50 & $\mathrm{mg} \mathrm{L}^{-1}$ & $\mathrm{~L}$ \\
\hline 9 & $\mathrm{NO}_{3}^{-}-\mathrm{N}$ & NIEA W415.51 B & 0.10 & $\mathrm{mg} \mathrm{L}^{-1}$ & $\mathrm{~L}$ \\
\hline 10 & $\mathrm{Ca}^{+2}$ & APHA(20th) 3500-Ca B & 0.50 & $\mathrm{mg} \mathrm{L}^{-1}$ & $\mathrm{~L}$ \\
\hline 11 & $\mathrm{Mg}^{+2}$ & NIEA W208.50 A & 0.30 & $\mathrm{mg} \mathrm{L}^{-1}$ & $\mathrm{~L}$ \\
\hline 12 & $\mathrm{Na}^{+}$ & APHA(19th) 3500-Na D & 0.50 & $\mathrm{mg} \mathrm{L}^{-1}$ & $\mathrm{~L}$ \\
\hline 13 & $\mathrm{~K}^{+}$ & APHA(19th) 3500-K D & 0.45 & $\mathrm{mg} \mathrm{L}^{-1}$ & $\mathrm{~L}$ \\
\hline 14 & $\mathrm{NH}_{4}^{+}-\mathrm{N}$ & NIEA W448.51 B & 0.025 & $\mathrm{mg} \mathrm{L}^{-1}$ & $\mathrm{~L}$ \\
\hline 15 & Fe total dissolved & NIEA W305.51 A & 0.038 & $\mathrm{mg} \mathrm{L}^{-1}$ & $\mathrm{~L}$ \\
\hline 16 & As total dissolved & NIEA W311.51 B & 0.010 & $\mathrm{mg} \mathrm{L}^{-1}$ & $\mathrm{~L}$ \\
\hline 17 & Sulfide & NIEA W433.50 A & 0.035 & $\mathrm{mg} \mathrm{L}^{-1}$ & $\mathrm{~L}$ \\
\hline
\end{tabular}

* Resolution.

Note: F, measured in field; L, measured in Lab. 
Water samples for the measurement of metal and other cations were first filtered with $0.45 \mu \mathrm{m}$ cellulose nitrate filters and then acidified with nitric acid (Merck ultrapure grade) to $\mathrm{pH}$ 2. Samples for sulfide analyses were collected in narrow-mouth biochemical oxygen demand (BOD) bottles $(300 \mathrm{ml})$ with tapered ground-glass stoppers and flared mouths. To avoid trapping or dissolving atmospheric oxygen, a rubber tube was extended from the pump line into the bottom of the sample bottle. The sample bottle was then flushed with water before being filled to the brim and sealed using a rubber stopper, ensuring no air bubbles remained in the bottle. Samples were then kept in ice boxes and delivered to the laboratory within 24 hours (Chen and Liu 2003, 2005).

Alkalinity (bicarbonate) of the water was determined by titration method and anions of $\mathrm{NO}_{3}{ }^{-}, \mathrm{SO}_{4}{ }^{2-}$ and chloride were determined using ion chromatography (IC) (Table 2). Ammonium and sulfide were determined by spectrophotometric techniques using the phenate and methylene blue methods, respectively (NIEA W448.51B, W433.50A). Total dissolved iron and arsenic were determined by atomic absorption spectrometric method and inductively coupled plasma technique, respectively. A total of 15 samples including blank, spiked, duplicate and check samples (standard solution from Merck) were measured sequentially (APHA 1998). The lower detection limits of methods are described in Table 2. Variances of duplicate measurements were lower than $10 \%$ and recoveries of check and spike samples were between 85 and $110 \%$.

PHREEQC (Parkhurst, USGS) is a geochemical computer program written in $\mathrm{C}$ programming language that is designed to perform a wide variety of low-temperature aqueous geochemical calculations. It has capabilities for onedimensional (1D) transport calculations involving reversible reactions, which include aqueous, mineral, gas, solidsolution, surface-complexation, and ion-exchange equilibria, and irreversible reactions, which include specified mole transfers of reactants, kinetically controlled reactions, mixing of solutions, and temperature changes. We use PHREEQC to calculate speciation, saturation-index and values of the redox potential of our sampled hot spring waters.

\section{WATER CHEMISTRY AND GEOLOGICAL BACKGROUND}

Our hot spring samples are classified into two geological backgrounds: the Tatun Volcano Group and the Western Foothills and Hsueshan-Central Ranges. Hot springs of the volcanic area are sulfur-enriched while those found in sedimentary and metamorphic rocks are dominated by chloride or bicarbonate (Fig. 1).

\subsection{Tatun Volcano Group}

The V1 and V2 hot springs are located at Chinshan of Taipei County, in the northern part of the Tatun Volcano
Group. The V3 is in Beitou, the south of the Tatun Volcano Group (Fig. 3a). Precisely, the V1 and V2 "hot springs" are not "natural" hot springs but are mixtures of stream water with fumarolic gas in a manmade construction (Fig. 3b). These mixtures of hot water are defined as one type of "hot spring" through the Hot Spring Act of Taiwan. The chemical compositions of these hot springs are dependent on parameters such as the chemical compositions of stream water, fumarolic gas and thermal water, the percentages of mixture, and chemical reactions (e.g., redox, precipitation/dissolution, etc.).

Those hot spring waters in the volcanic area have much lower $\mathrm{pH}$ values of $1.39 \sim 2.74$ compared to $6.76 \sim 8.62$ in the sedimentary and metamorphic area (Table 3 ). The high concentrations of hydrogen ion in hot springs were caused by the dissolution of hydrogen sulfide and sulfur dioxide gas into the waters. Hydrogen sulfide and sulfur dioxide are two major components found in fumarolic gases, which are both fairly soluble and dissolve very quickly (Mason and Moore 1982; Lee et al. 2005). The subsequent release of hydrogen ions decreases the $\mathrm{pH}$ of water as follows:

$\mathrm{H}_{2} \mathrm{~S}_{(\mathrm{aq})}=\mathrm{HS}^{-}+\mathrm{H}^{+}$

$\mathrm{SO}_{2(\mathrm{~g})}+\mathrm{H}_{2} \mathrm{O}=2 \mathrm{H}^{+}+\mathrm{SO}_{3}{ }^{-2}$ (aq)

When the $\mathrm{pH}$ value of water is lower than 4.50 , all bicarbonate ions are converted to carbon dioxide gas and there

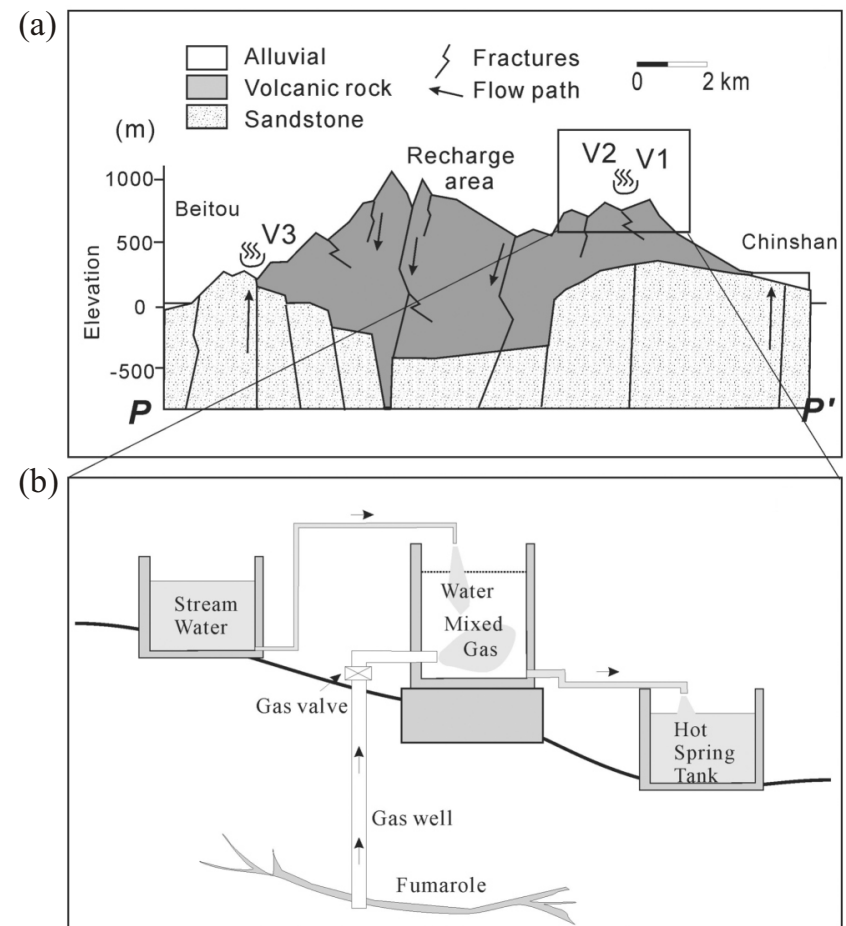

Fig. 3. (a) The occurrences of sampled hot springs in volcanic area (geology profile modified from Chen and Wu 1971). (b) The V1 and V2 hot springs are not "natural" but a mixture of stream water and fumarolic gas. 
Table 3. The field measured values of temperature, electrical conductivity (EC), pH, dissolved oxygen (DO), and redox potential (Eh) of sampled hot springs.

\begin{tabular}{cccccc}
\hline ID & Temperature $\left({ }^{\circ} \mathbf{C}\right)$ & $\mathbf{E C}\left(\mu \mathbf{S ~ c m} \mathbf{~ m}^{-1}\right)$ & $\mathbf{p H}$ & $\mathbf{D O}\left(\mathbf{m g ~ L}^{-1}\right)$ & $\mathbf{E h}(\mathbf{m V})$ \\
\hline V1 & $80.0 / 56.0$ & $286 / 503$ & $2.49 / 2.60$ & $2.81 / 2.55$ & $-65 / 493$ \\
V2 & $68.5 / 73.6$ & $275 / 329$ & $2.74 / 2.52$ & $2.74 / 3.06$ & $-145 / 95$ \\
V3 & $58.3 / 53.1$ & $5840 / 4130$ & $1.39 / 1.65$ & $3.90 / 5.84$ & $-23 / 382$ \\
S1 & $47.6 /$ & $18900 /$ & $7.14 /$ & $0.43 /$ & $-216 /$ \\
S2 & $41.3 / 41.8$ & $813 / 809$ & $8.55 / 8.42$ & $2.53 / 1.52$ & $-182 /-11$ \\
S3 & $46.1 / 40.9$ & $2340 / 2350$ & $6.76 / 6.89$ & $0.23 / 1.63$ & $-277 /-236$ \\
S4 & $30.1 / 65.4$ & $1216 / 1005$ & $8.00 / 8.62$ & $1.10 / 3.82$ & $-97 /-112$ \\
M1 & $57.7 / 54.1$ & $490 / 496$ & $7.72 / 7.81$ & $0.44 / 0.54$ & $-266 /-242$ \\
M2 & $58.2 / 58.9$ & $592 / 593$ & $7.82 / 7.90$ & $0.87 / 0.78$ & $-245 /-231$ \\
M3 & $33.9 / 48.5$ & $763 / 674$ & $8.18 / 8.15$ & $0.49 / 0.88$ & $-55 / 27$ \\
M4 & $59.0 / 50.0$ & $2040 / 2030$ & $6.95 / 7.00$ & $0.32 / 2.45$ & $-240 / 112$ \\
\hline
\end{tabular}

Note: The former values were measured in the source of outcrop or well head, the latter values were from the outlet of tanks.

will have no bicarbonate ions in the water.

As shown in Fig. 4 and Table 4, the dominating anions in the V1, V2, and V3 hot springs are sulfate, while the other hot spring waters are bicarbonate or chloride. We suggest that high percentages of sulfate in the V1, V2, and V3 are the final products of bisulfide and sulfite ions oxidation. The reducing sulfurs react with oxygen dissolved in surface water and from air, according to Eqs. (3) and (4).

$$
\begin{aligned}
& \mathrm{HS}^{-}+2 \mathrm{O}_{2(\mathrm{aq})}=\mathrm{H}^{+}+\mathrm{SO}_{4}{ }^{-2}(\mathrm{aq}) \\
& 2 \mathrm{SO}_{3}{ }^{-2}{ }_{(\mathrm{aq})}+\mathrm{O}_{2(\mathrm{aq})}=2 \mathrm{SO}_{4}{ }^{-2}{ }_{(\mathrm{aq})}
\end{aligned}
$$

High concentrations of intermediate sulfur species, e.g., bisulfite, sulfite, polysulfides, polythionate, and thiosulfate, are often found in acid crater lakes and some acid hot springs. However, sulfur is predominantly present as sulfate in aer-

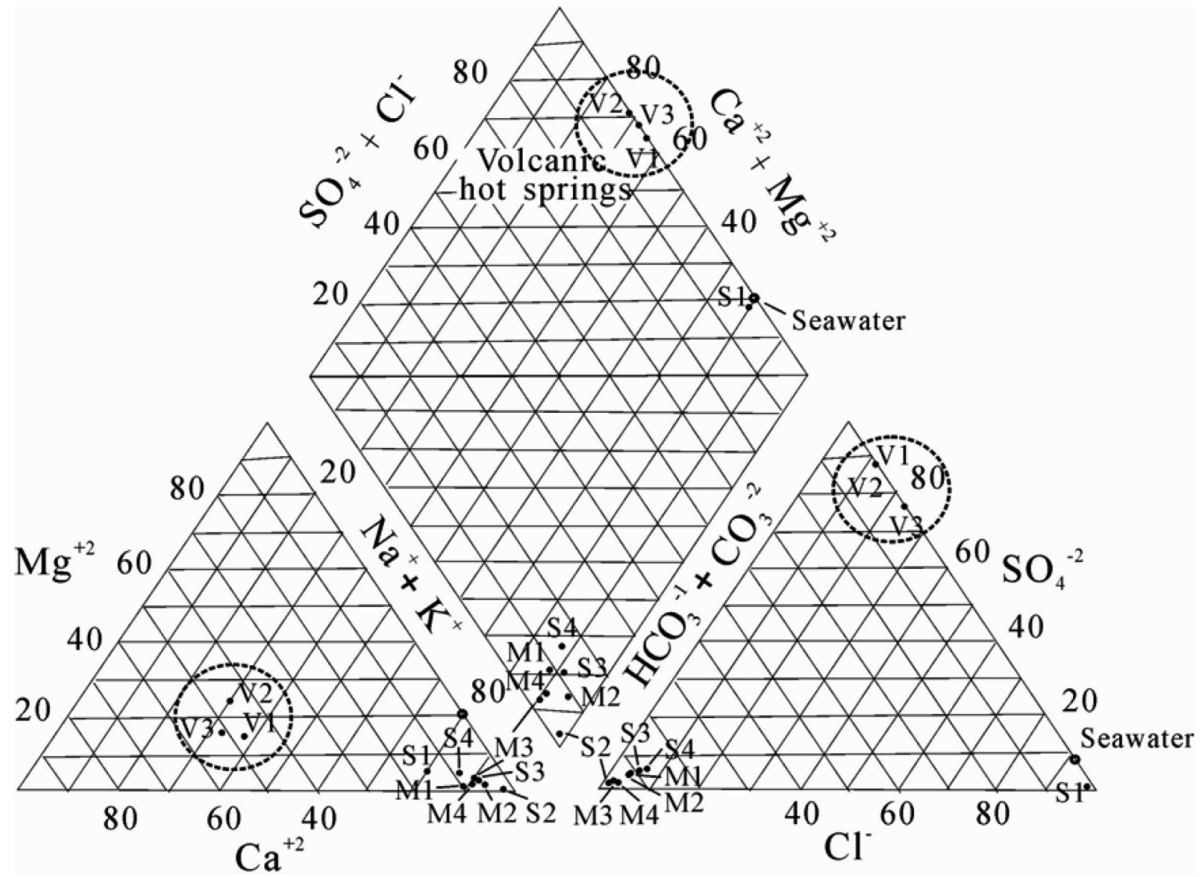

Fig. 4. Trilinear diagrams of major ions for the sampled hot springs. Number of samples please see Fig. 1. 
Table 4. Chemical compositions of sampled hot springs.

\begin{tabular}{|c|c|c|c|c|c|c|c|c|c|c|c|c|c|c|c|}
\hline \multirow[b]{2}{*}{ D } & EC & $\mathrm{Na}^{+}$ & $\mathbf{K}^{+}$ & $\mathbf{C a}^{+2}$ & $\mathrm{Mg}^{+2}$ & $\mathrm{HCO}_{3}^{-}$ & $\mathbf{F}^{-}$ & $\mathrm{Cl}^{-}$ & $\mathrm{Br}^{-}$ & $\mathrm{NO}_{3}^{-}$ & $\mathrm{SO}_{4}^{-2}$ & $\mathbf{F e}$ & As & $\mathrm{NH}_{4}{ }^{+}$ & Sulfide \\
\hline & $\mu \mathrm{S} \mathrm{cm}$ & $\mathrm{mg}$ & $\mathrm{mg} \mathrm{L}^{-1}$ & $\mathrm{mg} \mathrm{L}^{-1}$ & $\mathrm{mg} \mathrm{L}^{-1}$ & $\mathrm{mg} \mathrm{L}^{-1}$ & $\mathrm{mg} \mathrm{L}^{-1}$ & $\mathrm{mg} \mathrm{L}^{-}$ & $\mathrm{mg} \mathrm{L}^{-1}$ & $\mathrm{mg} \mathrm{L}^{-1}$ & $\mathrm{mg} \mathrm{L}^{-}$ & $\mathrm{mg} \mathrm{L}^{-1}$ & $\mathrm{mg} \mathrm{L}^{-}$ & $\mathrm{mg} \mathrm{L}^{-1}$ & $\mathrm{mg} \mathrm{L}^{-1}$ \\
\hline V1 & 388 & 7.3 & 3.8 & 8.9 & 3.2 & $<1.0$ & 0.28 & 9.1 & 0.39 & 0.36 & 96.4 & 0.94 & $<0.01$ & 1.10 & $>5$ \\
\hline $\mathrm{V} 2$ & 400 & 6.6 & $<0.1$ & 9.8 & 2.8 & $<1.0$ & 0.21 & 8.9 & $<0.1$ & 0.25 & 97.8 & 26.7 & 0.03 & 4.70 & $>5$ \\
\hline V3 & 8100 & 35.6 & 170 & 189 & 35.8 & $<1.0$ & 2.13 & 3 & $<0.1$ & 1.78 & 1740 & 3.34 & 0.69 & 5.49 & $>5$ \\
\hline S1 & 19070 & 3620 & 179 & 592 & 121 & 132 & 1.98 & 6960 & 23.4 & $<0.1$ & 17.8 & 0.32 & $<0.01$ & 54.8 & $<0.03$ \\
\hline S2 & 775 & 176 & 3.4 & 3.1 & 0.4 & 498 & 1.16 & 4.2 & $<0.1$ & $<0.1$ & 5.1 & 0.18 & $<0.01$ & $<0.025$ & 0.04 \\
\hline S3 & 2270 & 480 & 13.1 & 26 & 6.0 & 1300 & 1.27 & 65.3 & $<0.1$ & 0.49 & 48.7 & 0.21 & $<0.01$ & 5.24 & 0.09 \\
\hline S4 & 1025 & 225 & 28.8 & 17.7 & 7.6 & 504 & 1.12 & 21.6 & 1.33 & 7.36 & 45.0 & 0.05 & $<0.01$ & $<0.025$ & 0.24 \\
\hline M1 & 498 & 106 & 4.1 & 10.3 & 0.9 & 262 & 2.21 & 7.6 & $<0.1$ & $<0.1$ & 11.6 & 0.22 & $<0.01$ & 1.60 & $<0.03$ \\
\hline M2 & 594 & 131 & 4 & 8. & 0.6 & 328 & 2.76 & 8.45 & $<0.1$ & 0.25 & 14.1 & 0.07 & $<0.01$ & 2.47 & $<0.03$ \\
\hline M3 & 589 & 121 & 6.3 & 8.3 & 2.3 & 359 & 1.75 & 4.4 & 0.43 & 0.49 & 6.5 & 0.46 & $<0.01$ & 1.80 & $<0.03$ \\
\hline M4 & 1996 & 410 & 37.0 & 31.5 & 4.6 & 1116 & 4.3 & 23.1 & $<0.1$ & 1.9 & 11.4 & 0.10 & $<0.01$ & 13.9 & $<0.03$ \\
\hline
\end{tabular}

ated waters (Williamson and Rimstidt 1992; Xu et al. 1998).

Sulfate concentrations in hot springs will increase with the continuous influent of sulfide and the oxidization of sulfide unless sulfate minerals are precipitated. The saturation indices of the V1, V2, and V3 hot springs for anhydrite and gypsum range from -1.02 to -2.55 that are unsaturated with the sulfate minerals (Table 5).

Hot springs are hot-water-dominated or vapor-dominated systems (Whiter et al. 1971; Nordstrom et al. 2005). Hot springs in areas with fumaroles, such as V1, V2, and V3, are vapor-dominated. Volatile components, i.e., $\mathrm{H}_{2} \mathrm{~S}, \mathrm{CO}_{2}$,
$\mathrm{NH}_{3}, \mathrm{~N}_{2}$ are partitioned into the gas phase during boiling and affect the chemistry of vapor-dominated systems. The acid springs receives $\mathrm{H}_{2} \mathrm{~S}$ enriched gas that was oxidized to sulfur dioxide and sulfuric acid at or near the surface. Chloride normally stays in liquid phase during steam separation at boiling point near ambient pressures, whereas acid springs always have lower chloride and higher sulfate concentrations (Fig. 4).

The EC value of the $\mathrm{V} 3$ hot spring is $5840 \mu \mathrm{S} \mathrm{cm}^{-1}$, much higher than $\mathrm{V} 1$ and $\mathrm{V} 2$ of 286 and $275 \mu \mathrm{S} \mathrm{cm}^{-1}$ (Table 3), but the percentages of major anions for the three hot springs are

Table 5. Saturation indices of sampled hot springs for carbonate and sulfate.

\begin{tabular}{cccccccc}
\hline & $\begin{array}{c}\text { Agragonite } \\
\mathbf{C a C O}_{3}\end{array}$ & $\begin{array}{c}\text { Calcite } \\
\mathrm{CaCO}_{3}\end{array}$ & $\begin{array}{c}\text { Dolomite } \\
\mathbf{C a M g}\left(\mathbf{C O}_{3}\right)_{2}\end{array}$ & $\begin{array}{c}\text { Siderite } \\
\mathbf{F e C O}_{3}\end{array}$ & $\begin{array}{c}\text { Anhydrite } \\
\mathbf{C a S O}_{4}\end{array}$ & $\begin{array}{c}\text { Gypsum } \\
\mathbf{C a S O}_{4}: 2 \mathbf{H}_{2} \mathbf{O}\end{array}$ & $\begin{array}{c}\text { FeS } \\
\text { amorphous }\end{array}$ \\
\hline V1 & - & - & - & - & -2.54 & -2.55 & -6.50 \\
V2 & - & - & - & - & -2.45 & -2.45 & -4.55 \\
V3 & - & - & - & - & -1.02 & -1.03 & -8.40 \\
S1 & 0.46 & 0.58 & 1.01 & -0.53 & -2.16 & -2.17 & - \\
S2 & 0.36 & 0.48 & 0.68 & 0.93 & -4.31 & -4.32 & -2.17 \\
S3 & -0.06 & 0.06 & 0.01 & -0.11 & -2.52 & -2.53 & 0.14 \\
S4 & 0.66 & 0.78 & 1.73 & 0.12 & -2.59 & -2.60 & -1.21 \\
M1 & -0.01 & 0.11 & -0.31 & 0.45 & -3.24 & -3.25 & - \\
M2 & 0.06 & 0.18 & -0.24 & 0.08 & -3.29 & -3.29 & - \\
M3 & 0.42 & 0.54 & 1.08 & 1.14 & -3.65 & -3.66 & - \\
M4 & 0.18 & 0.30 & 0.30 & -0.26 & -3.02 & -3.03 & - \\
\hline
\end{tabular}

Note: The values of saturation index within $0 \pm 1.00$ are considered as saturated; $>1.00$ as over-saturated; and $<-1.00$ as unsaturated. 
quite similar (Fig. 4). The difference in EC values between $\mathrm{V} 1, \mathrm{~V} 2$, and V3 may be caused by evaporation of water that increases the concentrations of solutes. We found that these would be consistent with compositions of the V3 hot spring by removing $95 \%$ of water from the $\mathrm{V} 1$ and $\mathrm{V} 2$ hot springs (Tables 3, 4).

\subsection{Western Foothills and Hsueshan-Central Ranges}

The $\mathrm{S} 1$ is the only chloride-dominated hot spring (Fig. 4). Of the 8 sampled hot springs in sedimentary or metamorphic strata, all, except the S1 are near faults or fracture zones, which provide the circulation path for recharge to discharge (Tu and Chen 1991; Lo and Wu 1999; Fig. 5a). S1 is not a natural (artesian) hot spring. Its hot water comes from a well of $1500 \mathrm{~m}$ in depth, which is located on the Linkou Tableland, Taipei County (Fig. 1). The temperature of the groundwater is about $40-50^{\circ} \mathrm{C}$ under a depth of $1000-1500 \mathrm{~m}$ with

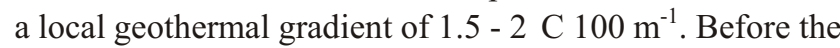
construction of the hot spring well, there was no natural hot spring on the Linkou Tableland.

The S1 hot spring well is sited on the high flat top of the tableland with underlying horizontal strata of Plio-Pleistocene semi-consolidated mud and sand layers without fault or fracture within a distance of $10 \mathrm{~km}$. The groundwaters in the deeper aquifers are isolated by overburden thick confining layers and it is hard to recharge from surface water. Because of poor circulation and relatively slight surfacefresh-water dilution, the composition of geothermal water at $\mathrm{S} 1$ is still similar to that of seawater, which was trapped in the pores of sediments deposited in marine environments (Fig. 4). $\mathrm{S} 1$ geothermal water has a $\mathrm{Na}^{+} / \mathrm{Cl}^{-}$mass ratio of 0.52 , which is comparable to seawater $(0.55)$. The concentrations of ions at $\mathrm{S} 1$ consistently lower than those of seawater at a ratio of $2.7 \sim 3$ (Table 4). According to the concentrations of $\mathrm{Na}^{+}, \mathrm{Cl}^{-}$, and $\mathrm{Br}^{-}$, the geothermal water may have been diluted by a volume of fresh water approximately 3 times that of the original trapped seawater. Sulfate concentration is only $17.8 \mathrm{mg} \mathrm{L}^{-1}$ in the $\mathrm{S} 1$ sample, wich is much lower than $2700 \mathrm{mg} \mathrm{L}^{-1}$ in seawater (Table 4). We suppose that a sulfate-reducing process has been occurred in the aquifer.

The hot springs of S2-S4 and M1-M4 are all sodium bicarbonate dominated (Fig. 4). Previous studies suggested that as the surface water (rainwater or stream water) moves through the aquifer, the groundwater chemistry changes via a three-step process (Chapelle 2001): First, carbonic acid is released by oxidation of organic matter in the soil and aquifer [Eq. (5)] or by dissolved atmospheric $\mathrm{CO}_{2}$ [Eq. (6); Appelo 1994]. Then, the acid dissolved $\mathrm{CaCO}_{3}$ (calcite) in the aquifer [Eq. (7)]. Finally, calcium cations are exchanged with sodium cations on clays of the aquifer [Eq. (8)].

$\mathrm{CH}_{2} \mathrm{O}+\mathrm{O}_{2}=\mathrm{H}_{2} \mathrm{CO}_{3}$
$\mathrm{CO}_{2}+\mathrm{H}_{2} \mathrm{O}=\mathrm{H}_{2} \mathrm{CO}_{3}$

$\mathrm{CaCO}_{3}+\mathrm{H}_{2} \mathrm{CO}_{3}=\mathrm{Ca}^{2+}+2 \mathrm{HCO}_{3}$

$\mathrm{Ca}^{2+}+2 \mathrm{Na}^{+}($on clay $)=\mathrm{Ca}^{2+}$ (on clay $)+\mathrm{Na}^{+}$

This hypothesis is used to explain the processes for forming the sodium bicarbonate dominated water of the hot springs that we studied. Fossils of calcite (or aragonite) composition are abundant in the marine-originated rocks of the Western Foothills and Hsueshan-Central Ranges of Taiwan, which provide the $\mathrm{CaCO}_{3}$ [as in Eq. (6)]. All of the 9 hot springs are saturated with aragonite and calcite, suggesting the presence of $\mathrm{CaCO}_{3}$ minerals in the aquifers (Table 5).

\section{REDOX POTENTIAL AND REDOX COUPLES}

\subsection{Field-Measured and Redox Couples-Computed Eh}

The measured Eh values at the sources of the 11 sampled hot springs are all lower than $0 \mathrm{mV}$ with a range from -23 to $-277 \mathrm{mV}$ that indicate a reducing condition (Table 3 ). However, there are oxidants - dissolved oxygen and nitrate, presented in the hot springs. Samples of V1, V2, V3, S2, and $\mathrm{S} 4$ contain DO with concentrations of 1.10 to $3.90 \mathrm{mg} \mathrm{L}^{-1}$ and $\mathrm{V} 3, \mathrm{~S} 4$, and $\mathrm{M} 4$ have nitrate of 1.78 to $7.36 \mathrm{mg} \mathrm{L}^{-1}$

(a)

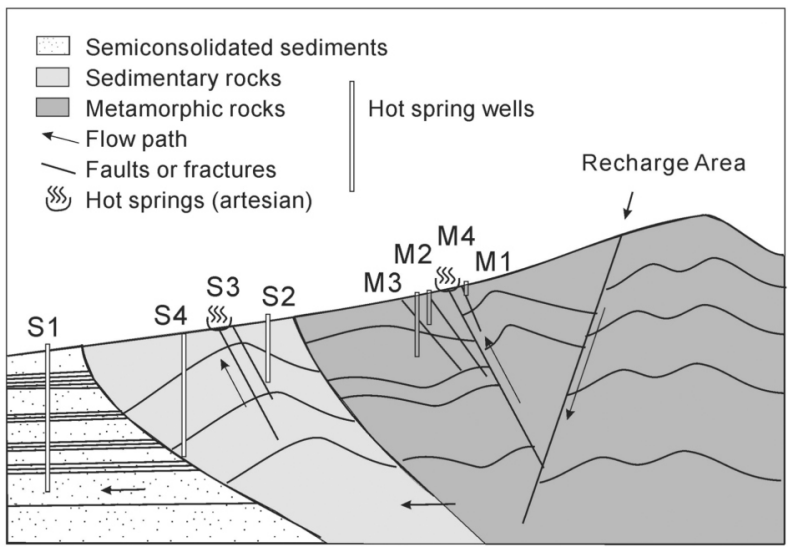

(b)

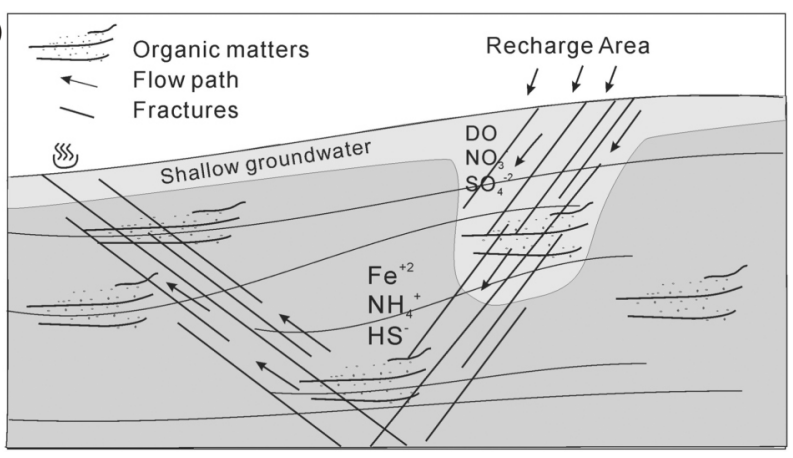

Fig. 5. (a) A schematic model (not to scale) showing the occurrences of the selected hot springs in sedimentary or metamorphic rocks. (b) The conceptual model for redox species of hot spring waters along the flow path in sedimentary and metamorphic rocks. 
(Table 4). Previous study suggests that some aqueous oxidation-reduction reactions were generally not at equilibrium in ground waters (Lindberg and Runnells 1984). They researched 611 analyses of ground waters from diverse geographic areas, which showed that measured Eh values were not consistent with computed values by redox couples when using the computer model WATEQFC (Runnells and Lindberg 1981). Redox agents (e.g., $\mathrm{O}_{2} / \mathrm{H}_{2} \mathrm{O}, \mathrm{HS}^{-} / \mathrm{SO}_{4}{ }^{-2}$, and $\mathrm{NO}_{3}{ }^{-} / \mathrm{NH}_{4}{ }^{+}$, etc.) in ground water and aquifer will interact with each other and change the Eh values.

DO is one of the most important oxidant in hot springs. The concentrations of DO at all the sources of our sampled hot spring are between $0.23 \sim 3.90 \mathrm{mg} \mathrm{L}^{-1}$ (Table 3). The detection limit of DO in our study is $0.2 \mathrm{mg} \mathrm{L}^{-1}$ for the WTW DO meter (Oxi 315), according to the manufacturer's certification. However, Radtke et al. (1998) recommended a spectrophotometric method for determining DO of lower than $1.0 \mathrm{mg} \mathrm{L}^{-1}$, which is a Rhodazine- $\mathrm{D}^{\mathrm{TM}}$ colorimetric technique with a sensitivity of $0.01 \mathrm{mg} \mathrm{L}^{-1}$ (ASTM 1984; White et al. 1991). Comparing the results measured by the membrane method and the spectrophotometric method, Chen and Liu (2003) suggested that the membrane method is unreliable when DO concentrations are lower than $0.5 \mathrm{mg} \mathrm{L}^{-1}$. In a practical way, they suggested that DO concentrations lower than $0.5 \mathrm{mg} \mathrm{L}^{-1}$ could be considered as anoxic.

Table 3 shows DO concentrations at the sources of the 11 hot springs, 5 are anoxic and 6 are with DO detected. All waters from the three hot springs (V1, V2, and V3) in the Tatun Volcano Group area contain DO. It is reasonable since the three hot springs are mixed with a high percentage of surface water. In pristine surface water and the unsaturated zone, oxygen is the most important oxidizing agent. The other three samples with DO detected (S2, S4, and M2) may have been mixed with shallow groundwaters while they flowed upward (Fig. 5b).

Figure 6 shows the comparison between field-measured and computed Eh values that were carried out from redox couples of $\mathrm{O}_{2} / \mathrm{H}_{2} \mathrm{O}, \mathrm{HS}^{-} / \mathrm{SO}_{4}{ }^{-2}$, and $\mathrm{NO}_{3}{ }^{-} / \mathrm{NH}_{4}{ }^{+}$. The Nernstian Eh values are calculated from the following equations (Parkhurst 1995).

$$
\begin{array}{ll}
\mathrm{O}_{2}+4 \mathrm{H}^{+}+4 \mathrm{e}^{-}=2 \mathrm{H}_{2} \mathrm{O} & \log \mathrm{K}=83.12 \\
\mathrm{NO}_{3}{ }^{-}+10 \mathrm{H}^{+}+8 \mathrm{e}^{-}=\mathrm{NH}_{4}{ }^{+}+3 \mathrm{H}_{2} \mathrm{O} & \log \mathrm{K}=119 \\
\mathrm{SO}_{4}{ }^{-2}+9 \mathrm{H}^{+}+8 \mathrm{e}^{-}=\mathrm{HS}^{-}+4 \mathrm{H}_{2} \mathrm{O} & \log \mathrm{K}=33.66
\end{array}
$$

We simplify the calculation by assuming that the concentration equals the values of method detection limit if the concentrations determined are below the detection limit. The Eh values computed by $\mathrm{O}_{2} / \mathrm{H}_{2} \mathrm{O}$ and $\mathrm{NO}_{3}{ }^{-} / \mathrm{NH}_{4}{ }^{+}$couples are higher than the field-measured values (Fig. 6). The largest computed values of Eh range from 600 to $1200 \mathrm{mV}$, as a result of the $\mathrm{O}_{2} / \mathrm{H}_{2} \mathrm{O}$ couple, while the field-measured
Eh values are only 0 to $-300 \mathrm{mV}$.

In theory, oxygen and nitrate are good oxidizing agents (Parkhurst 1995), that are demonstrated by a calculation with the water composition of the $\mathrm{S} 1$ hot spring, i.e., $\mathrm{pH} 7.14$, ammonium $54.8 \mathrm{mg} \mathrm{L}^{-1}$, sulfate $17.8 \mathrm{mg} \mathrm{L}^{-1}$, but concentrations of nitrate range from 1 to $10^{-5} \mathrm{mg} \mathrm{L}^{-1}$ (Fig. 7). Although nitrate concentration is low to $10^{-5} \mathrm{mg} \mathrm{L}^{-1}$, the value of $\mathrm{Eh}$ is $+168 \mathrm{mV}$, which implies that the hot spring water should have a positive value of Eh while it contains nitrate even with trace amount. Eight samples from our studied hot springs contain nitrate concentrations of 0.25 to $7.36 \mathrm{mg} \mathrm{L}^{-1}$ (Table 4), although those samples show negative field-measured Eh values (Fig. 6). By contrary, sulfide is a strong reducing agent and the computed Eh values are always below $-200 \mathrm{mV}$ even at a concentration of $10^{-5} \mathrm{mg} \mathrm{L}^{-1}$ (Fig. 7).

A water sample that contains ions of nitrate, ammonium, sulfide and DO is thermodynamically at non-equilibrium

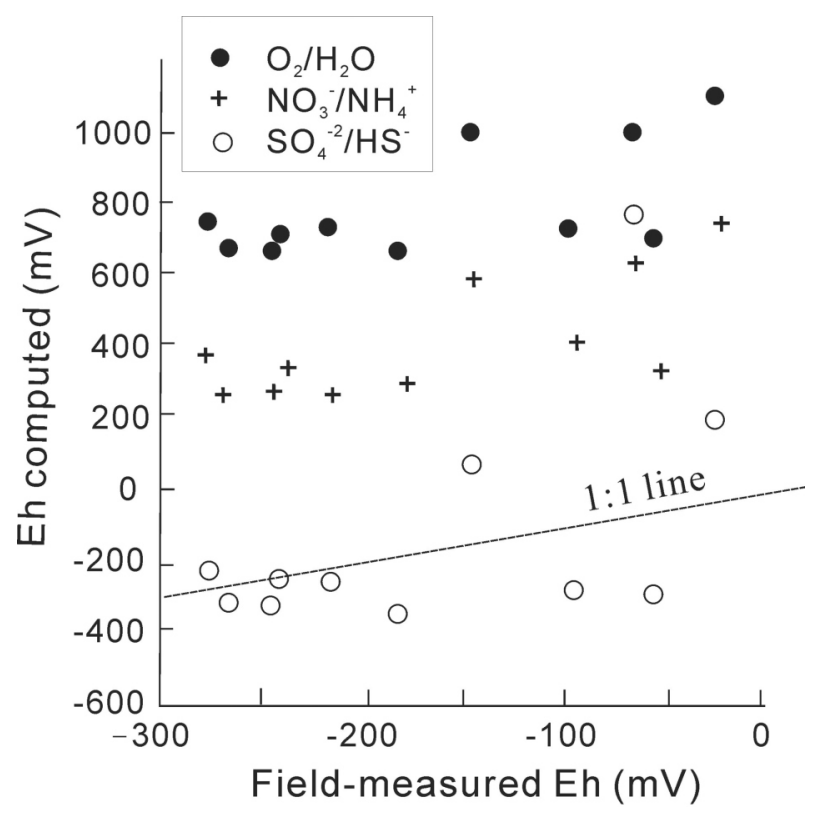

Fig. 6. Comparison between field-measured and computed Eh values.

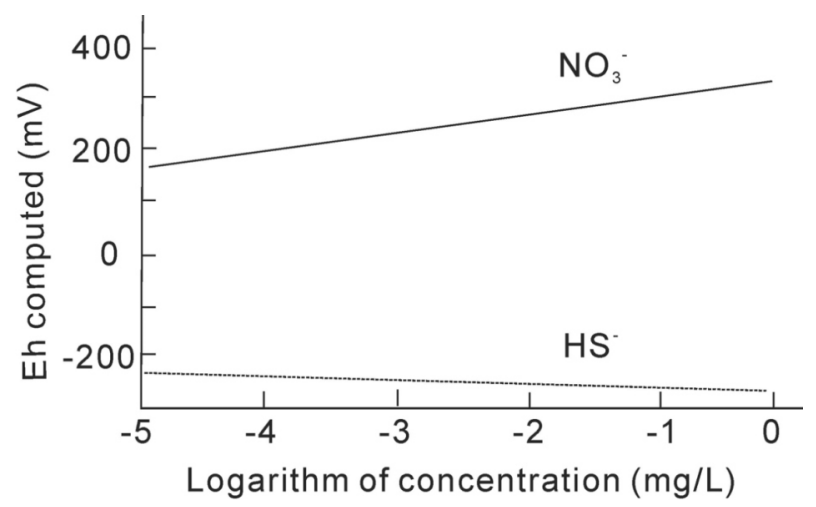

Fig. 7. The Eh computed-values for nitrate and sulfide with concentrations of 1 to $10^{-5} \mathrm{mg} \mathrm{L}^{-1}$. 
and its Eh value varies with time. In our experience, the precious-metal electrode of the Eh meter has different sensitivity with ions. In particular, it is a lot more sensitive in detecting concentration variations of ammonium and sulfide than nitrate and DO. A study reported that Eh electrode is not suitable for nitrate investigation (Wang et al. 2004). We measured Eh values by sensor (Mettler Switzerland) with tap water and some known ingredients in a batch test (Table 6). We found that there were negative Eh values for DO-contained waters (Tubes 4 and 5) while sulfide or ammonium was in the water too. The results confirm our interpretation of the Eh sensor as being more sensitive to sulfide and ammonium than DO and nitrate.

Hot springs or groundwaters in deep circulation (S1-S4, M1-M4) are usually in a reducing state because of a lack of oxygen gas and the waters react with mineral reducers in aquifers, e.g., pyrite, organic carbon, etc (Fig. 5b). The most natural oxidizing agents, dissolved oxygen and nitrate, usually distribute only in the shallow subsurface. Those hot spring waters containing DO (S2, S4, and M2) and nitrate (S3, S4, and M2-M4) should be mixed by shallow groundwaters.

\subsection{The Reducing Agents in Hot Spring Waters}

Ferrous iron, arsenic (III), sulfide and ammonium are the main reducers in our sampled hot springs (Table 4). V1, $\mathrm{V} 2$, and V3 hot springs contain high concentrations of dissolved hydrogen sulfide ( $\left.>5 \mathrm{mg} \mathrm{L}^{-1}\right)$ and sulfur dioxide gas, which are important electron donors as expressed in Eqs. (3) and (4). According to a study of fumarolic gas composition in the Tatun Volcano Group (Lee et al. 2005), concentrations of hydrogen sulfide were higher than sulfur dioxide in mass ratios of $\mathrm{H}_{2} \mathrm{~S} / \mathrm{SO}_{2}$ from 120 to 167 . Sulfur occurs in a variety of oxidation states: $-2,0,2,4$, and 6 , while sulfide has the lowest oxidation state of -2 . After hot springs come in contact with oxygen, sulfide is oxidized to sulfate $(+6)$ through intermediates such as elemental sulfur $(0)$, thiosulfate $(+2)$ and sulfite $(+4)$ (Nordstrom 1982; Crossman and Desrocher 2001). The study of Yellowstone hot springs concluded that upon discharge of sulfide-containing hydrothermal water, oxidation proceeds rapidly as atmospheric oxygen enters the water (Xu et al. 1998). The transfer of oxygen is particularly effective if the hydrothermal discharge is turbulent and has a large surface area.

Except for reducing sulfur in volcanic hot springs, the V1, V2, and V3 waters also contain high concentration of dissolved iron with 0.94 - $26.7 \mathrm{mg} \mathrm{L}^{-1}$ (Table 4). The iron may be dissolved by acid waters from mafic minerals in the concrete tanks or volcanic rocks on the ground surface. The iron ion will be in the reduced state of ferrous ion $\left(\mathrm{Fe}^{+2}\right)$ while the $\mathrm{pH}$ is 1.39 to 2.74 and $\mathrm{Eh}$ is -100 to $780 \mathrm{mV}$ (Brookins 1988). The field-measured Eh values of V1, V2, and $\mathrm{V} 3$ hot springs were $-145,-65$, and $-23 \mathrm{mV}$, respectively (Table 3). Although V2 hot spring has a very high concentration of $\mathrm{Fe}^{+2}\left(26.7 \mathrm{mg} \mathrm{L}^{-1}\right)$, it is unsaturated for FeS precipitations along with V1 and V3 (Table 5). Dissolved oxygen in those hot springs could be an oxidant to the ferrous ion, but reduced sulfur compounds, such as dissolved sulfide or thiosulfate, are important inhibitors to ferrous oxidation (Nordstrom et al. 2005). The reduced sulfur compounds act also as reducers for ferric oxides to ferrous iron in the acid hot springs.

In the non-volcanic area, sulfide in groundwaters usu-

Table 6. A batch test of the Eh measured-values for five different redox couples.

\begin{tabular}{|c|c|c|c|c|c|c|}
\hline \multirow{2}{*}{ Tubes } & \multirow{2}{*}{ Ingredients } & \multirow{2}{*}{ Redox Couple } & \multirow{2}{*}{$\mathbf{p H}$} & DO & Eh & EC \\
\hline & & & & $\mathrm{mg} \mathrm{L}^{-1}$ & $\mathrm{mV}$ & $\mu \mathrm{S} \mathrm{cm} \mathrm{cm}^{-1}$ \\
\hline \multirow[t]{2}{*}{1} & Tap Water & $\mathrm{H}_{2} \mathrm{O} / \mathrm{DO}$ & 7.50 & 5.06 & 294 & 310 \\
\hline & & & 7.43 & 5.98 & 278 & 247 \\
\hline \multirow[t]{2}{*}{2} & $\mathrm{NaNO}_{3}$ & $\mathrm{NO}_{3}{ }^{-} / \mathrm{N}_{2}$ & 7.19 & 5.72 & 286 & 1585 \\
\hline & & & 7.33 & 5.23 & 273 & 1577 \\
\hline \multirow[t]{2}{*}{3} & $\mathrm{FeCl}_{2}$ & $\mathrm{Fe}^{+2} / \mathrm{Fe}^{+3}$ & 6.26 & 4.83 & -86.3 & 793 \\
\hline & & & 6.22 & 4.56 & -84.8 & 783 \\
\hline \multirow[t]{2}{*}{4} & $\mathrm{Na}_{2} \mathrm{~S}$ & $\mathrm{~S}^{-2} / \mathrm{SO}_{4}^{-2}$ & 11.30 & 5.02 & -209 & 1182 \\
\hline & & & 11.40 & 4.19 & -239 & 1154 \\
\hline \multirow[t]{2}{*}{5} & $\mathrm{NH}_{4} \mathrm{Cl}$ & $\mathrm{NH}_{4}^{+} / \mathrm{NO}_{3}^{-}$ & 7.32 & 5.73 & -88 & 1001 \\
\hline & & & 7.26 & 5.32 & -33 & 1015 \\
\hline
\end{tabular}

Note: The values of $p H, D O, E h$, and EC were measured by electrical sensors, please see text. In the Tubes 2 to 5 , ingredients were added into tap water. For two measurements in one test, the first set of values was recorded in one minute after the test began and the second set was recorded in ten minutes. 
ally results from bacterial sulfate reduction (Stumm and Morgan 1995; Chapelle 2001). The general reaction is:

$2 \mathrm{CH}_{2} \mathrm{O}+\mathrm{SO}_{4}^{-2}=\mathrm{H}_{2} \mathrm{~S}+2 \mathrm{HCO}_{3}^{-}$

where $\mathrm{CH}_{2} \mathrm{O}$ is a representative organic compound. Sulfate reduction requires reducing potentials with values lower than $-150 \mathrm{mV}$ (Postgate 1984). The threshold sulfate concentration required for acetotrophic sulfate reduction to proceed is approximately $2.9 \mathrm{mg} \mathrm{L}^{-1}$ (Lovley and Klug 1986; Kirk et al. 2004). Sulfate concentrations of the 8 hot springs (S1-S4 and M1-M4) are 5.1 $48.7 \mathrm{mg} \mathrm{L}^{-1}$, which are all higher than the threshold value of $2.9 \mathrm{mg} \mathrm{L}^{-1}$. It is possible that all 8 hot springs have on going the sulfatereducing process in their aquifers. But only three hot springs (S2, S3, and S4) with higher concentrations of sulfate are sulfide detectable $\left(>0.03 \mathrm{mg} \mathrm{L}^{-1}\right)$ (Table 4$)$. The $\mathrm{S} 3$ and $\mathrm{S} 4$ hot springs have higher sulfate concentrations of 48.7 and $45.0 \mathrm{mg} \mathrm{L}^{-1}$, with sulfide concentrations of 0.09 and $0.24 \mathrm{mg} \mathrm{L}^{-1}$, respectively (Table 4). We suggest that the other hot springs with sulfate $>2.9 \mathrm{mg} \mathrm{L}^{-1}$ may contain sulfide but its under our detection limit.

9 of the 11 hot spring samples contain ammonium (Table 4). Hot springs or groundwaters with detectable concentrations of ammonium $\left(\mathrm{NH}_{4}{ }^{+}\right)$also indicate a reducing conditions. Ammonium is a commonly found component in anaerobic groundwaters and fine-grained layer aquifers, attributed to the degradation of complex organic material disseminated in aquifers that are organic-rich and poor in circulation (Schilling 2002). Thermodynamically, ammonium exists in the Eh range from -200 to $-400 \mathrm{mV}$ while $\mathrm{pH}$ is between 7.0 to 7.5 (Brookins 1988).

The measured Eh value of the $\mathrm{S} 1$ hot spring is $-216 \mathrm{mV}$ with a concentration of ammonium $54.8 \mathrm{mg} \mathrm{L}^{-1}$, which is the highest value among the 11 hot springs (Table 4). This may be because the water came from a deep confined sedimentary aquifer that is organic-rich. The second highest ammonium concentration (13.9 $\left.\mathrm{mg} \mathrm{L}^{-1}\right)$ is the M4 hot spring, which is situated in the area of metamorphic rock in the Central Range. Ammonium was found in minerals of metamorphic and granitic rocks and is one of the stable geochemical components in high temperature processes (Honma and Itihara 1981). There is no report on the ammonium concentration of hot spring water in Taiwan before this study. In our investigation from 2004 to 2006, a large percentage of hot springs contained ammonium, e.g., Guanzihling 0.60, Lushan 6.8 - 18.9, Dongpu 2.41, Jiaosi 5.70, and Jhihben 16.6, all in units of $\mathrm{mg} \mathrm{L}^{-1}$ (unpublished data).

The V1, V2, and V3 hot springs in the volcanic area also have ammonium with concentrations ranging from 1 to $6 \mathrm{mg} \mathrm{L}^{-1}$ (Table 4). Research shows that high ammonium concentrations are interpreted as being related to areas where a convection system has developed, coinciding with the most recent volcanic centers located along rift zones and with main features inside caldera (Hernandez et al. 2004). Ammonium concentrations up to $880 \mathrm{mg} \mathrm{L}^{-1}$ at Washburn Hot Spring of Yellowstone National Park were reported and had been attributed to leaching of sedimentary rock by hydrothermal solutions (Holloway et al. 2003; McCleskey et al. 2004). Hot spring waters in Kamchatka, one of the most active regions of volcanism, contained ammonium $21 \sim 46 \mathrm{mg} \mathrm{L}^{-1}$ with Eh -141 -301 mV (Zhao et al. 2005).

Ammonium levels in the minerals of granites are averaging $45 \mathrm{mg} \mathrm{kg}^{-1}$ and range from 10 to $100 \mathrm{mg} \mathrm{kg}^{-1}$ (Hall et al. 1994; Hall 1999). Ammonium contents are strongly enriched in the hydrothermally altered rocks, including greisens and kaolinized granites. A previous hypothesis suggests that the ammonium in the granites is derived from a sedimentary source, either in the magmatic source region or via contamination of the magma (Kohut and Pieczka 2003). In summary, ammonium is a common and quite stable compound through the volcanic environment (Marfil et al. 1998).

\section{IMPLICATIONS}

\subsection{Arsenic Species in the Beitou Hot Spring Area}

The release of arsenic from geothermal systems into surface and ground waters inhibits its use as drinking water. In surface waters, arsenic contamination also adversely affects aquatic ecosystems by accumulating in sediments and plants (Webster and Nordstrom 2003). Recent news and reports show great concern over arsenic in the hot spring of the Geothermal Valley in the Beitou district of Taipei. The authorities are concerned whether arsenic poses a serious danger to either hot spring enthusiasts or rice consumers.

The valence state of arsenic plays an important role in its behavior and toxicity in aqueous system. Arsenic compounds with a +3 oxidation state are more toxic than analogous compounds with a +5 oxidation state, e.g., arsenite versus arsenate (Jain and Ali 2000; Smedley and Kinniburgh 2002; Aposhian et al. 2003). According to data from the Taipei City Government's Department of Environmental Protection and Taipei Water Department, the amount of soluble arsenic in the white sulfur hot springs (V1 and V2) was $0.002 \mathrm{mg} \mathrm{L}^{-1}$, and for the green sulfur hot spring (V3) 0.5 $3.0 \mathrm{mg} \mathrm{L}^{-1}$. However, the valence state of arsenic is not clear. In our study, the concentrations of total dissolved arsenic of $\mathrm{V} 1, \mathrm{~V} 2$, and V3 are $<0.01,0.03$, and $0.69 \mathrm{mg} \mathrm{L}^{-1}$, respectively (Table 4). We simulate arsenic species in the V3 hot spring water by the geochemical program PHREEQC (Parkhurst 1995) to predict the transformation of arsenic species under different redox conditions. The calculated Eh value of the V3 is $187 \mathrm{mV}$ by assuming that the sulfide/sulfate is the major redox couple in the hot spring (Table 7). The species of arsenic is As(III)-dominated with a concentration of $0.69 \mathrm{mg} \mathrm{L}^{-1}$ while $\mathrm{As}(\mathrm{V})$ is $1.0 \times 10^{-6} \mathrm{mg} \mathrm{L}^{-1}$ (Table 7).

While discharge of the hot spring is delivered to a tank or pool, oxidation proceeds rapidly as atmospheric oxygen 
Table 7. Simulation of arsenic species for the V3 hot spring by PHREEQC, for assuming sulfide/sulfate being the dominant couple.

\begin{tabular}{|c|c|c|c|c|}
\hline \multicolumn{2}{|c|}{ Input } & \multicolumn{3}{|c|}{ Calculated Results } \\
\hline $\mathrm{pH}$ & 1.39 & Redox couple & pe & Eh (volts) \\
\hline temp & $58.3^{\circ} \mathrm{C}$ & $\mathrm{S}(-2) / \mathrm{S}(6)$ & 2.85 & 0.187 \\
\hline units & ppm & & & \\
\hline $\mathrm{Ca}$ & 189 & Species & & Molality \\
\hline $\mathrm{Mg}$ & 35.8 & $\operatorname{As}(3)$ & & $9.23 \times 10^{-6}$ \\
\hline $\mathrm{Na}$ & 35.6 & $\mathrm{H}_{3} \mathrm{AsO}_{3}$ & & $9.0 \times 10^{-6}$ \\
\hline $\mathrm{Cl}$ & 393 & $\mathrm{H}_{4} \mathrm{AsO}_{3}^{+}$ & & $2.3 \times 10^{-7}$ \\
\hline Alkalinity & 0.00 as $\mathrm{HCO} 3$ & $\mathrm{H}_{2} \mathrm{AsO}_{3}^{-}$ & & $5.1 \times 10^{-13}$ \\
\hline$S(6)$ & 1740 & $\mathrm{HAsO}_{3}{ }^{-2}$ & & $7.1 \times 10^{-23}$ \\
\hline $\mathrm{O}(0)$ & 2.74 & $\mathrm{AsO}_{3}^{-3}$ & & $5.6 \times 10^{-34}$ \\
\hline$N(-3)$ & 5.49 & $\operatorname{As}(5)$ & & $1.4 \times 10^{-11}$ \\
\hline $\mathrm{N}(5)$ & 1.78 & $\mathrm{H}_{3} \mathrm{AsO}_{4}$ & & $1.2 \times 10^{-11}$ \\
\hline $\mathrm{S}(-2)$ & 5.0 & $\mathrm{H}_{2} \mathrm{AsO}_{4}^{-}$ & & $1.0 \times 10^{-12}$ \\
\hline $\mathrm{Fe}$ & 3.34 & $\mathrm{HAsO}_{4}{ }^{-2}$ & & $1.5 \times 10^{-17}$ \\
\hline As & 0.69 & $\mathrm{AsO}_{4}{ }^{-3}$ & & $5.8 \times 10^{-27}$ \\
\hline
\end{tabular}

enters the water. The ions of As(III) in water will be oxidized to $\mathrm{As}(\mathrm{V})$. Field investigations at a hot spring in Yellowstone National Park revealed rapid arsenite oxidation occurring within the drainage channel (Giring et al. 2001; Schwenzer et al. 2001). The oxidation of hot spring water during storage and delivery will increase the Eh value. Studies in Japan also observed that the natural spring waters have lower Eh values than those exposed to air (Shoichi et al. 1999, 2000).

The Eh values of V1, V2, and V3 hot springs in tanks are 493, 95, and $382 \mathrm{mV}$, respectively (Table 3 ). The $\mathrm{pH}$ values of the three hot springs did not exhibit significant change, only within the range of \pm 0.3 . As the hot springs aged in lower $\mathrm{pH}$, the sulfide volatilized as hydrogen sulfide gas and dissipated. This process remarkably changes the Eh value, making it more positive. We suggest that Eh values of 498 and $382 \mathrm{mV}$ in V1 and V3 hot springs are caused by hydrogen sulfide dissipation rather than by sulfide oxidation (Fig. 8). After all the sulfide dissipates, As(III) will be the next to be oxidized. It will occur in Eh $500 \mathrm{mV}$ for the V3 hot spring with a $\mathrm{pH}$ value of 1.39 (Fig. 8).

\subsection{Ammonium and Hot Spring Disinfection}

Hot springs which feature high levels of minerals and elevated temperatures are potentially ideal venues for pathogen growth (e.g., Naegleria, Acanthamoeba, and Legionella) or contamination by users with enteric illness. Acquisition of sporadic community-acquired Legionnaires' disease has been linked to hot spring baths. Outbreaks of hot spring-associated Legionnaires' disease were reported in Japan during the last few years (Furuhata et al. 2004; Yabuuchi and Agata 2004). Legionella was found to be present in more than $20 \%$ of the water samples taken from hot spring resorts (Hsu et al. 2006; Lin et al. 2007). The Center for Disease Control (CDC) of Taiwan also indicates that Legionella has been detected in hot water supply systems and urges SPA and hot spring business owners to clean their tubs and change bathing water regularly. According to the guidelines of CDC, to prevent Legionella outbreaks, it is necessary to maintain optimal SPA water quality by chlorine disinfection, e.g., free chlorine $2 \sim 3 \mathrm{mg} \mathrm{L}^{-1}$, and $\mathrm{pH} 7.2 \sim 7.8$. (CDC-US 1981; WHO 2000; CDC-T 2006).

Chlorine is one of the most widely used disinfectants. It is very applicable and effective for the deactivation of patho-

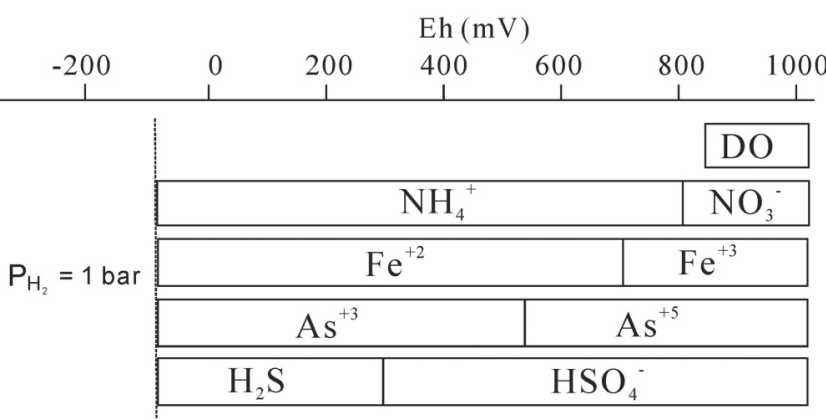

Fig. 8. The Eh diagram for some common found redox couples in hot spring waters of $\mathrm{pH} 1.39$ (Data from Brookins 1988). 
genic microorganisms. Chlorine is easily applied, measured, and controlled. It is fairly persistent and relatively cheap. However, many hot springs in Taiwan have high concentrations of ammonium and in that case adding chlorine will produce chloramines, which in large quantities are toxic and odorous (Isaac and Morris 1983; Brezonik 1994; Duong et al. 2003; Wei et al. 2006). Another disadvantage of using ammonium-containing hot spring water is that at higher $\mathrm{pH}$ (i.e., $\mathrm{pH}>8$ ) more ammonium will be converted to ammonia gas giving off a fetid odor, something that is not conducive to a good SPA resort. We suggest that the disinfection of ammonium-contained hot spring water should exclude chlorination and with a $\mathrm{pH}$ value kept at between 6 to 8 .

\subsection{Volcanological Forecasting and Earthquake Precursors}

The concentration of hydrogen sulfide and its derivative species are good indicators for monitoring fumarolic activity in volcanic areas (Zimbelman et al. 2000; McGee et al. 2001; Symonds et al. 2001; Chiodini et al. 2002; Tassi et al. 2003). Ammonium may be used as another useful indicator for geochemical surveillance of volcanic activity. A good correlation between vertical soil movements and variations in ammonium concentrations have been observed (Valetino and Stanzione 2004). In Taiwan, volcanic activity monitoring is still at its early stage, monitoring data on concentrations of hydrogen sulfide, ammonium and Eh value in thermal water and fumarolic gas are scarce and should be studied in the future.

In nonvolcanic areas, hot spring waters usually circulate to a great depth along a fault or fracture zones. Song et al. (2005) found that hot springs from deeper reservoirs are superior to shallow circulating springs and groundwater shows concentration anomalies correlating with earthquake events. Studies recommend that some of the geochemical items of hot springs, e.g., radon (Kuo et al. 2006; Yasuoka et al. 2006), chloride (Toutain et al. 1997; Toutain and Baubron 1999), calcium, sodium, sulfate, etc. (Biagi et al. 2001) would be capable of serving as earthquake precursors and fault activity indicators. However, case studies on ammonium and sulfide are rare. A study shows that ammonium concentrations in stream water from the upper reaches of Guandaushi Creek in Nantou County increased by 20 to 40 times from August 1998 to September 1999 before the 921 Earthquake (Liu 2007). We suggest that the ammonium may have come from deeper anoxic aquifers and discharged into the Guandaushi Creek through an unknown fault zone. Hot springs that circulate from the deeper part of the fault zone contain dissolved reducing agents such as hydrogen sulfide and ammonium, which make for ideal monitoring species.

\section{CONCLUSIONS}

A total of 11 hot springs located at 9 different areas across Taiwan were surveyed: 3 sites are in the Tatun Volcano Group, 4 in the Western Foothill, 3 in the Hsueshan Range and 1 in the Central Range. The measured values of Eh are all lower than $0 \mathrm{mV}$ and range from -23 to $-277 \mathrm{mV}$, indicating reducing conditions for the hot spring waters. Most of the samples from the sources contained sulfide and ammonium. In the Tatun Volcano Group, hot springs originating from the mixture of fumarolic gas and water had high concentrations of hydrogen sulfide, which is the dominant reducing agent. Ammonium, with concentrations ranging from 1 to $55 \mathrm{mg} \mathrm{L}^{-1}$, is another important electron donor in the hot springs of Taiwan.

We found that there were negative Eh measured-values for DO-containing waters (both in field and lab) while sulfide or ammonium was in the waters, too. The results confirm the interpretation that the Eh sensor is more sensitive to sulfide and ammonium than DO and nitrate.

We suggest that hot springs with deep circulation (S1 $\mathrm{S} 4, \mathrm{M} 1$ - M4) are in a reducing state because there is a lack in oxygen gas and the waters will react with mineral reducers, e.g., pyrite and organic carbon. The most natural oxidizing agents, dissolved oxygen and nitrate, usually distribute only in the shallow subsurface. Those hot spring waters containing DO (S2, S4, and M2) and nitrate (S3, S4, and M2-M4) should be mixed with groundwaters in the shallow aquifers.

We also simulate the redox condition for V3 (TienHsyang) hot spring by the geochemical program PHREEQC and predict that As(III) will be the dominant species with Eh value of $187 \mathrm{mV}$ and $\mathrm{pH}$ of 1.39 . This calculation should be useful for future studies.

There are disadvantages in using ammonium-containing hot spring waters in the Spa industry since it is not suitable for chlorine disinfection and ammonium converts to ammonia gas giving off a fetid odor in higher $\mathrm{pH}$.

We suggest that ammonium and sulfide in hot springs, which usually occur in deep circulation along faults or in fissures of volcanic areas, may be good indicators for earthquake and volcanic activity monitoring.

Acknowledgements The authors wish to thank Profs. S. Z. Lee, K. C. Yu, and Y. F. Chang at Chia-Nan University for their useful comments and suggestions. This study is supported financially by National Science Council (NSC94-2116-M-041-002) and the Water Resources Agency, Ministry of Economic Affairs, Taiwan.

\section{REFERENCES}

APHA, 1998: Standard Methods for the Examination of Water and Wastewater, Clescerl, L. S., A. E. Greenberg, A. D. Eaton (Eds,) $20^{\text {th }}$ Ed., American Public Health Assoc., Wasington DC.

Aposhian, H. V., R. A. Zakharyan, M. D. Avram, M. J. Kopplin, and M. L. Wollenberg, 2003: Oxidation and detoxification of trivalent arsenic species. Toxicol. Appl. Pharmacol., 
193, 1-8, doi: 10.1016/S0041-008X(03)00324-7. [Link]

Appelo, C. A. J., 1994: Cation and proton exchange, pH variations, and carbonate reactions in a freshening aquifer. Water Resour. Res., 30, 2793-2805, doi: 10.1029/94WR 01048. [Link]

ASTM, 1984: Power Plant Water Analysis Manual, $1^{\text {st }}$ Ed., American Society for Testing and Materia, Philadelphia, PA, USA, 169-171.

Biagi, P. F., R. Piccolo, A. Ermini, Y. Fjunawa, S. P. Kingsley, Y. M. Khatkevich, and E. I. Gordeev, 2001: Hydrogeochemical precursors of strong earthquakes in Kamchatka: Further analysis. Nat. Hazards Earth Syst. Sci., 1, 9-14.

Brezonik, P. L., 1994: Chemical Kinetics and Process Dynamics in Aquatic Systems, Lewis Publishers, Boca Raton, Florida, USA.

Brookins, D. G., 1988: Eh-pH Diagrams for Geochemistry, Springer-Verlag, New York, USA.

CDC-T, 2006: Suggested health and disinfection guidelines for hot spring bathtubs. Taipei, Taiwan, Department of Health, http://www.health.gov.tw/.

CDC-US, 1981: Suggested health and safety guidelines for public spas and hot tubs. Atlanta, GA: US Department of Health and Human Services, Public Health Service, CDC, DHHS publication no. (CDC) 99-960.

Chapelle, F. H., 2001: Ground-Water Microbiology and Geochemistry, John Wiley, New York, 477 pp.

Chen, C. H. and Y. T. Wu, 1971: Volcanic geology of the Tatun geothermal area, northern Taiwan. Proc. Geol. Soc. China, 14, 5-20.

Chen, W. F. and T. K. Liu, 2003: Dissolved oxygen and nitrate of groundwater in Choshui fan-delta, Western Taiwan. Environ. Geol., 44, 731-737, doi: 10.1007/s00254-0030823-0. [Link]

Chen, W. F. and T. K. Liu, 2005: Ion activity products of iron sulfides in groundwater: Implications from the Choshui fan-delta, western Taiwan. Geochim. Cosmochim. Acta, 69, 3535-3544, doi: 10.1016/j.gca.2005.03.007. [Link]

Chiodini, G., T. Brombach, S. Caliro, C. Cardellini, L. Marini, and V. Dietrich, 2002: Geochemical indicators of possible ongoing volcanic unrest at Nisyros Island (Greece). Geophys. Res. Lett., 29, 1759, doi: 10.1029/2001GL014355. [Link]

Crossman, E. L. and S. Desrocher, 2001: Microbial sulfur cycling in terrestrial subsurface. In: Fredrickson, J. K. and M. Fletcher (Eds.), Subsurface Microbiology and Biogeochemistry, Wiley-Liss, New York, 219-248.

Duong, H. A., M. Berg, M. H. Hoang, H. V. Pham, H. Gallard, W. Giger, and U. von Gunten, 2003: Trihalomethane formation by chlorination of ammonium- and bromide-containing groundwater in water supplies of Hanoi, Vietnam. Water Res., 37, 3242-3252, doi: 10.1016/S0043-1354(03) 00138-6. [Link]

ERL (Energy and Resources Laboratories, Industrial Technology Research Institute), 1999-2003: A study on the investigation, exploitation and utilization of hot-spring re- sources in Taiwan. Report for the Water Resource Agency, Ministry of Economic Affairs. (in Chinese)

Furuhata, K., M. Har, S. Yoshida, and M. Fukuyama, 2004: Distribution of Legionella spp. in hot spring baths in Japan. Kansenshogaku Zasshi., 78/8, 710-716.

Gihring, T. M., G. K. Druschel, R. B. McCleskey, R. J. Hamers, and J. F. Banfield, 2001: Rapid arsenite oxidation by thermus aquaticus and thermus thermopilus: Field and laboratory investigations. Environ. Sci. Technol., 35, 3857-3862, doi: 10.1021/es010816f. [Link]

Hall, A., 1999: Ammonium in granites and its petrogenetic significance. Earth-Sci. Rev., 45, 145-165, doi: 10.1016/ S0012-8252(99)00006-9. [Link]

Hall, A., M. G. Stamatakis, and J. N. Walsh, 1994: Ammonium enrichment associated with diagenetic alteration in Tertiary pyroclastic rocks from Greece. Chem. Geol., 118, 173-183, doi: 10.1016/0009-2541(94)90175-9. [Link]

Hem, J. D., 1992: Study and interpretation of the chemical characteristics of natural water. US Geological Survey, Water Supply Paper 2254.

Hernández, P. A., N. M. Pérez, J. M. L. Salazar, R. Ferrell, and C. E. Álvarez, 2004: Soil volatile mercury, boron and ammonium distribution at Canadas caldera, Tenerife, Canary Islands, Spain. Appl. Geochem., 19, 819-834, doi: 10.1016/ j.apgeochem.2003.12.003. [Link]

Holloway, J. M., J. K. Bohlke, and D. K. Nordstrom, 2003: Bedrock nitrogen and hydrothermal ammonium in Yellowstone National Park, WY, USA. EOS Trans. AGU, 84, Fall Meet. Suppl., Abstract B21D-0740.

Honma, H. and Y. Itihara, 1981: Distribution of ammonium in minerals of metamorphic and granite rocks. Geochim. Cosmochim. Acta, 45, 983-988, doi: 10.1016/0016-7037 (81)90122-8. [Link]

Hsu, B. M., C. H. Chen, M. T. Wang, and H. W. Cheng, 2006: Legionella prevalence in hot spring recreation areas of Taiwan. Water Res., 40, 3267-3273, doi: 10.1016/j.watres. 2006.07.007. [Link]

Isaac, R. A. and J. C. Morris, 1983: In: Water Chlorination, Ann Arbor Science, Ann Arbor, MI.

Jain, C. K. and I. Ali, 2000: Arsenic: Occurrence, toxicity and speciation techniques. Water Res., 34, 4304-4312, doi: 10.1016/S0043-1354(00)00182-2. [Link]

Kirk, M. F., T. R. Holm, J. Park, Q. Jin, R. A. Sanford, B. W. Fouke, and C. M. Bethke, 2004: Bacterial sulfate reduction limits natural arsenic contamination in groundwater. Geology, 32, 953-956, doi: 10.1130/G20842.1. [Link]

Kohút, M. and A. Pieczka, 2003: Ammonium content in the Hercynian granites of the Western Carpathians and its petrogenetic significance. GeoLines, 16, 53-54.

Kuo, T., K. Fan, H. Kuochen, Y. Han, H. Chu, and Y. Lee, 2006: Anomalous decrease in groundwater radon before the Taiwan M 6.8 Chengkung earthquake. J. Environ. Radioact., 88, 101-106, doi: 10.1016/j.jenvrad.2006.01.005. [Link]

Lee, H. F., T. F. Yang, T. F. Lan, S. R. Song, and S. Tsao, 2005: Fumarolic gas composition of the Tatun Volcano Group, 
Northern Taiwan. Terr. Atmos. Ocean. Sci., 16, 843-863.

Lin, Y. E., W. M. Lu, H. I. Huang, and W. K. Huang, 2007: Environmental survey of Legionella pneumophila in hot springs in Taiwan. Toxicol. Environ. Health A, 70, 84-87, doi: 10.1080/15287390600754987. [Link]

Lindberg, R. D. and D. D. Runnells, 1984: Ground water redox reactions: An analysis of equilibrium state applied to Eh measurements and geochemical modeling. Science, 225, 925-927, doi: 10.1126/science.225.4665.925. [Link]

Liu, C. P. and B. H. Sheu, 2007: Effects of the 921 earthquake on the water quality in the upper stream at the Guandaushi experimental forest. Water, Air, Soil Pollut., 179, 19-27, doi: 10.1007/s11270-006-3097-9. [Link]

Lo, W. and L. C. Wu, 1999: Explanatory text and geologic map of Taiwan, Kouhsing, scale 1:50,000, sheet 25, central geological survey, Taipei, Taiwan, ROC.

Lovley, D. R. and M. J. Klug, 1986: Model for the distribution of sulfate reduction and methanogenesis in freshwater sediments. Geochim. Cosmochim. Acta, 50, 11-18, doi: 10.1016/0016-7037(86)90043-8. [Link]

Marfil, R., A. Hall, S. Garcia-Gil, and M. G. Stamatakis, 1998: Petrology and geochemistry of diagenetically altered tuffacious rocks from the Middle Triassic of central Spain. $J$. Sediment. Res., 68, 391-403.

Mason, B. and C. B. Moore, 1982: Principles of Geochemistry, $4^{\text {th }}$ Ed., Wiley, New York, 344 pp.

McCleskey, R. B., J. W. Ball, D. K. Nordstrom, J. M. Holloway, and H. E. Taylor, 2004: Water-chemistry data for selected hot springs, geysers, and streams in Yellowstone National Park, Wyoming, 2001-2002. US Geological Survey OpenFile Report 2004-1316.

McGee, K. A., M. P. Doukas, and T. M. Gerlach, 2001: Quiescent hydrogen sulfide and carbon dioxide degassing from Mount Baker, Washington. Geophys. Res. Lett., 28, 44794482, doi: 10.1029/2001GL013250. [Link]

MRSO, 1969: The geothermal resources exploration report I of Tatun volcano group, Taiwan. MRSO Report, 90. (in Chinese)

MRSO, 1970: The geothermal resources exploration report II of Tatun volcano group, Taiwan. MRSO Report, 102. (in Chinese)

MRSO, 1971: The geothermal resources exploration report III of Tatun volcano group, Taiwan. MRSO Report, 111. (in Chinese)

MRSO, 1973: The geothermal resources exploration report IV of Tatun volcano group, Taiwan. MRSO Report, 126. (in Chinese)

MRSO, 1975: The geothermal resources exploration report I of Taiwan. MRSO Report, 146. (in Chinese)

MRSO, 1977: The geothermal resources exploration report II of Taiwan. MRSO Report, 163. (in Chinese)

MRSO, 1978: The geothermal resources exploration report III of Taiwan. MRSO Report, 170. (in Chinese)

MRSO, 1979: The geothermal resources exploration report IV of Taiwan. MRSO Report, 174. (in Chinese)
MRSO, 1980: The geothermal resources exploration report V of Taiwan. MRSO Report, 181. (in Chinese)

NIEA (Environmental Analysis Laboratory, Environment Protection Administration of Taiwan), 2005: Standard methods, http://www.niea.gov.tw/.

Nordstrom, D. K., 1982: Aqueous pyrite oxidation and the consequent formation of secondary iron minerals. In: Kittrick, J. A., D. S. Fanning, and L. R. Hossner, (Eds.), Acid Sulfate Weathering. Madison, WI. Soil Sci. Soc. Am. Special Publication, 10, 37-56.

Nordstrom, D. K., J. W. Ball, and R. B. McCleskey, 2003: Orpiment solubility equilibrium and arsenic speciation for a hot spring at Yellowstone National Park using revised thermodynamic data. Geological Society of America Abstracts with Programs, 35, 47-60.

Nordstrom, D. K., J. W. Ball, and R. B. McCleskey, 2005: Ground water to surface water - Chemistry of thermal outflows in Yellowstone National Park. In: Inskeep, W. and T. R. McDermott (Eds.), Geothermal Biology and Geochemistry in Yellowstone National Park: Bozeman, Mont., Thermal Biology Institute, Montana State University, USA, 73-94.

Parkhurst, D. L., 1995: User's guide to PHREEQC - a computer program for speciation, reaction-path, advective-transport, and inverse geochemical calculations: Water-Resources Investigations Report, 95-4227, US Geological Survey, Lakewood, Colorado.

Postgate, J. R., 1984: The Sulphate Reducing Bacteria, $2^{\text {nd }}$ Ed., Cambridge University Press, London.

Radtke, D. B., A. F. White, J. V. Davis, and F. D. Wilde, 1998: Dissolved oxygen. In: Wilde, F. D. and D. B. Radtke (Eds), Handbooks for Water-resources Investigations, chapter A6, Field Measurements, USGS, 38 pp.

Runnells, D. D. and R. D. Lindberg, 1981: WATEQFC: Hydrogeochemical exploration for uranium ore deposits: Use of the computer model WATEQFC. J. Geochem. Explor., 15, 37-50, doi: 10.1016/0375-6742(81)90054-6. [Link]

Schilling, K. E., 2002: Occurrence and distribution of ammonium in Iowa groundwater. Water Environ. Res., 74, 177186, doi: 10.2175/106143002X139893. [Link]

Schwenzer, S. P., C. E. Tommaseo, M. Kersten, and T. Kirnbauer, 2001: Speciation and oxidation kinetics of arsenic in the thermal springs of Wiesbaden spa, Germany. Fresenius J. Anal. Chem., 371, 927-933, doi: 10.1007/s002160101038. [Link]

Shoichi, O., S. Koyuki, S. Masaki, and K. Yasuo, 1999: Relationship between ORP (redox potentials) and $\mathrm{pH}$ in hot and cold spring waters and in human skins. J. Balneol. Soc. Jpn., 49, 59-64.

Shoichi, O., S. Koyuki, S. Masaki, and K. Yasuo, 2000: Relationship between ORP (oxidation reduction potential) and $\mathrm{pH}$ in spring waters of carbon dioxide type. J. Balneol. Soc. Jpn., 50, 94-101.

Smedley, P. L. and D. G. Kinniburgh, 2002: A review of the source, behaviour and distribution of arsenic in natural wa- 
ters. Appl. Geochem., 17, 517-568, doi: 10.1016/S08832927(02)00018-5. [Link]

Song, S. R., Y. L. Chen, C. M. Kiu, W. Y. Ku, H. F. Chen, Y. J. Liu, L. W. Kuo, T. F. Yang, C. H. Chen, T. K. Liu, and M. Lee, 2005: Hydrochemical changes in spring waters in Taiwan: Implications for evaluating sites for earthquake precursory monitoring. Terr. Atmos. Ocean. Sci., 16, 745-762.

Stumm, W. and J. J. Morgan, 1995: Aquatic Chemistry. Wiley Interscience, New York, USA.

Symonds, R. B., T. M. Gerlach, and M. H. Reed, 2001: Magmatic gas scrubbing: Implications for volcano monitoring. J. Volcanol. Geotherm. Res., 108, 303-341, doi: 10.1016/ S0377-0273(00)00292-4. [Link]

Tassi, F., O. Vaselli, B. Capaccioni, J. L. Macias, A. Nencetti, G. Montegrossi, and G. Magro, 2003: Chemical composition of fumarolic gases and spring discharges from El Chichòn volcano, Chiapas, Mexico: Causes and implications of the changes detected over the period 1998-2000. J. Volcanol. Geotherm. Res., 123, 105-121, doi: 10.1016/S0377-0273 (03)00031-3. [Link]

Toutain, J. P., and J. C. Baubron, 1999: Gas geochemistry and seismotectonics: A review. Tectonophysics, 304, 1-27, doi: 10.1016/S0040-1951(98)00295-9. [Link]

Toutain, J. P., M. Munoz, F. Poitrasson, and A. C. Lienard, 1997: Springwater chloride ion anomaly prior to a $\mathrm{ML}=$ 5.2 Pyrenean earthquake. Earth Planet. Sci. Lett., 149, 113-119, doi: 10.1016/S0012-821X(97)00066-6. [Link]

Tu, M. K. and W. C. Chen, 1991: Explanatory text and geologic map of Taiwan, Chutung, scale 1:50,000, sheet 13, Central Geological Survey, Taipei, Taiwan, ROC.

Valetino, G. M. and D. Stanzione, 2004: Geochemical monitoring of the thermal waters of the Phlegraean Fields. J. Volcanol. Geotherm. Res., 133, 261-289, doi: 10.1016/S03770273(03)00402-5. [Link]

Wang, Y. Y., Y. Z. Peng, C. Y. Peng, S. Y. Wang, and W. Zeng, 2004: Influence of ORP variation, carbon source and nitrate concentration on denitrifying phosphorus removal by DPB sludge from dephanox process. Water Sci. Technol., 50, 153-161.

Webster, J. G. and D. K. Nordstrom, 2003: Geothermal arsenic. In: Welch, A. H. and K. G. Stollenwerk (Eds), Arsenic in Ground Water, 101-125, Kluwer Academic Publishers.

Wei, D. B., L. S. Wang, J. Wei, and H. Y. Hu, 2006: Effects of chlorine disinfection on toxicity formation in reclaimed water. Bull. Environ. Contam. Taxico., 76, 226-232, doi: 10.1007/s00128-006-0911-4. [Link]

White, A. F., M. L. Peterson, and R. D. Solbau, 1991: Measurement and interpretation of low levels of dissolved oxygen in ground water. Ground Water, 28, 584-590, doi: 10.1111/ j.1745-6584.1990.tb01715.x. [Link]

White, D. E., L. J. P. Muffler, and A. H. Truesdell, 1971: Vapor-dominated hydrothermal systems compared with hotwater systems. Econ. Geol., 66, 75-97, doi: 10.2113/ gsecongeo.66.1.75. [Link]

WHO (WORLD HEALTH ORGANIZATION), 2000: Guidelines for Safe Recreational-water Environments: Vol. 2: Swimming Pools, Spas and Similar Recreational-water Environments Final Draft for Consultation.

Williamson, M. A. and J. D. Rimstidt, 1992: Correlation between structure and thermodynamic properties of aqueous sulfur species. Geochim. Cosmochim. Acta, 56, 3867-3880, doi: 10.1016/0016-7037(92)90002-Z. [Link]

WRA (Water Resource Agency), 2003: Hot Springs Act, http:// eng.wrs.gov.tw/.

Xu, Y., M. A. A. Schoonen, D. K. Nordstrom, K. M. Cunningham, and J. W. Ball, 1998: Sulfur geochemistry of hydrothermal waters in Yellowstone National Park: I. the origin of thiosulfate in hot spring waters. Geochim. Cosmochim. Acta, 62, 3729-3743, doi: 10.1016/S0016-7037(98)00269-5. [Link]

Yabuuchi, E. and K. Agata, 2004: An outbreak of legionellosis in a new facility of hot spring bath in Hiuga City. Kansenshogaku Zasshi, 78, 90-98.

Yasuoka, Y., G. Igarashi, T. Ishikawa, S. Tokonami, and M. Shinogi, 2006: Evidence of precursor phenomena in the Kobe earthquake obtained from atmospheric radon concentration. Appl. Geochem., 21, 1064-1072, doi: 10.1016/ j.apgeochem.2006.02.019. [Link]

Yen, T. P., 1955: Hot springs of Taiwan. Bank Taiwan Quart., 7, 129-147. (in Chinese)

Zhao, W., C. S. Romanek, G. Mills, J. Wiegel, and C. L. Zhang, 2005: Geochemistry and microbiology of hot springs in Kamchatka, Russia. Geol. J. China Univ., 11, 217-223.

Zimbelman, D. R., R. O. Rye, and G. P. Landis, 2000: Fumaroles in ice caves on the summit of Mount Rainier - preliminary stable isotope, gas, and geochemical studies. $J$. Volcanol. Geotherm. Res., 97, 457-473, doi: 10.1016/ S0377-0273(99)00180-8. [Link] 